\title{
Exploring Iranian EFL Teachers' Perspectives on Task-based Language Teaching
}

\section{Shahrzad Amini*1, Farzad Mahmoudi Largani ${ }^{2}$, \& Behnam Hedayat ${ }^{3}$}

\footnotetext{
* Correspondence:

Shahrzad.Amini@ut.ac.ir

1. University of Tehran, Iran

2. Tonekabon Branch, Islamic Azad

University, Tonekabon, Iran

3. Fasa University of Medical Sciences,

Fasa, Iran
}

Received: 21 June 2019

Revision: 8 September 2019

Accepted: 7 October 2019

Published online: 20 December 2019

\begin{abstract}
By the advent of communicative language teaching, the view of language researchers has altered from focusing on grammatical form towards meaning-based approaches to second language acquisition. But, less inclination is found in researchers to investigate into teachers' attitudes regarding the implementation of such an approach to classroom instruction. The purpose of this study is to investigate Iranian high school and private institute teachers' knowledge and attitude toward Task and Task-based Language Teaching. Furthermore, the reasons for choosing or avoiding implementing TBLT in the classrooms are investigated. So, a questionnaire consisting of four main parts was administered to 117 high school and institute teachers in Shiraz. Descriptive analysis indicated that the high school and institute teachers had good knowledge of TBLT principles. Moreover, they had positive attitudes toward TBLT, indicating a welcoming atmosphere toward the implementation of TBLT. Generally, no significant difference was found between the two groups of teacher. The findings revealed that the basic reason for implementing TBLT was the fact that it integrates the four language skills. Large classroom size and unfamiliarity of learners with TBLT were the basic reasons for avoiding the implementation of TBLT. The results suggested that EFL teachers can be hopeful to successfully apply TBLT in their classes, in both contexts.
\end{abstract}

Keywords: attitudes, EFL teachers, high school, private institute, task-based language teaching 


\section{Introduction}

Task-based Language Teaching (TBLT), developed from communicative language teaching methodology, has emerged in response to some limitations of the traditional process of presentation, practice, and performance approach (PPP) (Ellis, 2003; Long \& Crookes, 1992). To a great extent, the introduction of TBLT into the world of language teaching was largely in reaction to empirical accounts of teacher-dominated, form-oriented second language classroom practice (Long \& Norris, 2009). TBLT follows a learner-centered educational philosophy (Ellis, 2003; Nunan, 2011) and it supports content-oriented meaningful activities rather than linguistic forms (Beglar \& Hunt, 1999; Carless, 2002).

In task-based learning of language, learners are focused on the communication of meaning through interaction with the task (Long \& Crookes, 1992). Language in TBLT is employed for authentic purpose and learners have to consider language form in general rather than focusing on a distinct form. The purpose of TBLT is to integrate all four skills and to move from fluency to accuracy (Alavi, 2003). Richards and Rodgers (2001) defined TBLT as an approach which emphasizes the use of tasks as the heart of planning and instruction in language teaching. Ellis and Shintani (2014) also stated that TBLT is an approach aims to expand learners' communicative competence by engaging them in meaning-focused communication through the performance of tasks.

Willis and Willis (2009) claimed that Task-Based Approach is commonly considered as an effective teaching approach which is superior to traditional methods and it is firmly based in theory and research. Benevides and Valvona (2008) defined TBLT as a communicative approach to language teaching, using the successful completion of communicative tasks as its primary organizing principle. According to Willis (1996), in TBLT learners are provided with situations that help them experience natural exposure (input), opportunities to use language to state what they mean (output), to concentrate on improving their own language and to analyze and practice forms.

\subsection{Statement of the Problem}

Exploring teachers' perceptions and beliefs has been considered as a significant topic in both second and foreign language classrooms since teachers are considered as active decision makers whose beliefs and perceptions of classroom instructions play a key role in shaping and determining classroom events (Borg, 2006; Farrell \& Kun, 2007). During the last two decades, several studies have concentrated on language teacher cognition (Borg, 2006 \& 2012); however, studies on teachers' beliefs concerning tasks and TBLT are still very limited. Considering the popularity of TBLT in the form of curriculum and textbook production worldwide (Littlewood, 2004), the study of the topic seems to be necessary. In the Iranian context, as Mahdavirad (2017) stated, teachers' perceptions of task and task features and their attitudes towards the implementation of task-based language teaching have not yet been sufficiently emphasized. Moreover, the majority of the studies conducted on TBLT have considered teachers' perception in language institutes and high school teachers have been neglected. In Iran, where English is considered as a foreign language and learners are exposed to the language only in high schools and private institutes, studying teachers' perceptions of TBLT in both contexts would provide valuable insights.

\subsection{Objective of the Study}

In this study, language institute and high school teachers' perception of task and TBLT are compared to determine if there are any differences among the views of these two groups of teachers. It is also the objective of the study to investigate for what practical reasons English as a foreign language teachers choose to implement task-based language teaching and what would be their reasons in case they avoid implementing TBLT techniques.

\subsection{Research Questions}

To comply with the objectives of the study, the following research questions were formulated:

1. Is there any significant difference between high school and private institute teachers' knowledge of task?

2. Is there any significant difference between high school and private institute teachers' perceptions of TBLT?

3. Is there any significant difference between high school and private institute teachers' attitude towards the implementation of TBLT?

4. What are the reasons for using and avoiding the implementation of TBLT in the two educational contexts? 


\subsection{Research Hypotheses}

The present study also attempted to test the following hypotheses:

$\mathrm{H}_{01}$ : There is no significant difference between high school and private institute teachers' knowledge of task.

$\mathrm{H}_{02}$ : There is no significant difference between high school and private institute teachers' perceptions of TBLT.

$\mathrm{H}_{03}$ : There is no significant difference between high school and private institute teachers' attitude towards the implementation of TBLT.

\section{Review of the Literature}

Over the past three decades, task and task-based language teaching and learning became a hot topic among SecondLanguage Acquisition (SLA) and First Language Acquisition (FLA) researchers. A vast body of studies has concentrated on how to prepare and design task materials and how to put them into practice (Long \& Crookes, 1992; Nunan, 1988; Parrott, 1993). A number of other studies have examined the variability involved in learners' task performance, such as the conditions and characteristics of the tasks and their effect on learners' L2 production (Ellis, 2006; Skehan \& Foster, 1999). Another line of research studied TBLT from a different perspective, which is perceptions, views, and reasons to use or avoid TBLT employment in the classroom (Bernard \& Nguyen, 2010; Jeon \& Hahn, 2006; Tabatabaei \& Hadi, 2011).

In a study conducted by Ellis (2006), the methodological procedures for teaching tasks and specifically those procedures that are associated with how the tasks specified in a task-based syllabus can be changed into actual lessons as conducted by teachers in the classroom were considered. Drawing on the findings of a number of research studies, he mainly presented insightful ideas concerning the implementation of the well-established approach of 'pre-task, during the task, and post task' to task-based language teaching.

With respect to teachers' view of TBLT, Jeon and Hahn (2006) studied teachers' perceptions of task-based language teaching in Korean EFL situation. It was found that the teachers believed that specifically in an Asian English as a foreign language (EFL) context where learners are limited in their accessibility to use language on a daily basis; it seems necessary to provide the learners with ample opportunities to be exposed to real language use in the classroom situation within the framework of task-based language teaching.

In similar line, Ilin, Inozu, and Yumru (2007) explored teachers' and learners' perception of task-based language learning found that teacher's understanding of task-based teaching matched the definitions proposed by previous studies. However, its implementation in the classroom was confined only to language practice activities centering mainly on form. The study also revealed that the learners' consider the tasks as a means of revision at the end of a lesson due to the teacher's practice.

Bogali (2009) also conducted a study to explore college EFL instructors' and learners' perceptions of TBLT and to examine the degree they employ TBLT principles in their classes. Based on the results of the study, most of teachers and more than half of learners had high levels of perception about TBLT theories. The study also indicated that there was a difference between teachers' and learners' perceptions of TBLT method, and what they really use in EFL classes.

In similar vein, Xiongyong and Moses (2011) sought to study EFL teachers' perceptions of TBLT and the effect on their classroom practices to determine challenges and possibilities in TBLT implementation. According to the findings of the study, most teachers had positive attitudes toward TBLT implementation because of a higher level of perception on TBLT concepts. Yet, there were limitations like the large-sized class and complexity in students' task-based performance assessment.

In the context of public school, Lin and $\mathrm{Wu}$ (2012) studied 136 high school teachers in Taiwan to determine their attitudes and understandings of TBLT. The study indicated that teachers had both positive attitudes and understanding of tasks and task-related issues. They also claimed that issues such as inflexible syllabus, the number of students in the classroom, exam-oriented system, and limited teaching time confined the implementation of TBLT in the classroom.

Pohan, Andhini, Nopitasari, and Levana (2016) conducted a study to explore state junior, senior, and vocational high schools teachers' perception of TBLT in English classroom practice. More specifically, the study focused on teachers' 
perceptions of TBLT, their views regarding TBLT implementation, and the reason to employ or avoid TBLT implementation in the classroom. Findings of the study revealed that the majority of the teachers had good perceptions and positive attitudes/views of TBLT.

Liu, Mishan, and Chambers (2018) sought to investigate EFL teachers' perceptions of task-based language teaching in higher education in China. A mixed-method methodology was employed with quantitative and qualitative data collected through questionnaires and interviews. The findings of the study indicated that there is potential for the positive implementation of TBLT in the Chinese context. Most of the Chinese English Language Teaching (ELT) teachers had positive views on TBLT implementation and reported a high frequency of using TBLT. However, the majority of the participants were not confident in their perception of TBLT, though they were willing to attend training sessions. Additionally, the study revealed that the public examination system is one of the key reasons that impede the implementation of TBLT.

In another study, Pham and Nguyen (2018) examined teachers' perceptions about task-based language teaching and its implementation in classroom. In order to investigate the perceptions of sixty-eight university teachers, questionnaire and interviews were conducted. The findings indicated positive perceptions and understanding of teachers towards task-based language teaching.

In Iranian EFL context, several scholars attempted to explore teachers' perception of TBLT. For example, Tabatabaei and Hadi (2011) tried to explore Iranian EFL teachers' perceptions of task-based language pedagogy. Data regarding teachers' perceptions towards TBLT were collected using a questionnaire and the data were analyzed qualitatively and quantitatively. The results revealed that most teachers understand TBLT concepts and principles very well and there are just a few negative views on the implementation of this approach in English classrooms of Iran.

In another study, Mahdavirad (2017) sought to examine EFL teachers' perspectives regarding TBLT in Iranian context. The data for the study were collected through questionnaires at 20 different language institutes in Iran. The findings of the study indicated that the majority of Iranian EFL teachers have a clear understanding about TBLT concepts. However, there exists some negative views about implementing TBLT with regard to its classroom practice.

Also, Ansari and Shahrokhi (2014) suggested that teachers' beliefs regarding language and language learning affect the way they employ instructional practices in the classroom. Therefore, they tried to explore teachers' beliefs in a survey study. The study indicated that despite teachers' clear perception of TBLT principles, the majority of the teachers stated their reluctance to implement TBLT techniques in classroom.

\section{Methodology}

\subsection{Design of the Study}

The present study used survey research design where a questionnaire was distributed among instructors in public and private sectors to collect their opinions regarding aspects of task-based language teaching. In this study, participants' perceptions of the very concept of task, task-based language teaching and its principles and techniques, their interest in the implementation of task-based language lessons, and their reasons for implementing/ avoiding TBLT in their classes were explored.

\subsection{Participants}

As the purpose of this survey study was to explore instructors' attitude toward task-based language teaching, two groups of instructors were selected. It was decided that private institute instructors who are presently making use of TBLT procedures in their classes and high school instructors working in the southern city of Shiraz be involved. High schools instructors were randomly selected from 46 different schools located in four districts of education in Shiraz. Teachers of private institute were selected from Navid Institute. Table 1 shows the demographic information of teachers in both groups. 
Table 1. Demographic information of participants

\begin{tabular}{llll}
\hline & & Frequency & Percent \\
\hline \multirow{2}{*}{ Gender } & Male & 49 & 42 \\
& Female & 68 & 58 \\
\hline \multirow{2}{*}{ Instructors } & Institute & 63 & 54 \\
& High Schools & 54 & 46 \\
\hline \multirow{3}{*}{ Years of } & Less than 5 & 47 & 40 \\
experience & 10 to 20 & 21 & 18 \\
& more than 20 & 32 & 28 \\
& 20 to 29 & 41 & 14 \\
\hline \multirow{3}{*}{ Age } & 30 to 39 & 44 & 35 \\
& 40 to 49 & 23 & 37 \\
& $>50$ & 9 & 20 \\
\hline
\end{tabular}

As Table 1 indicates, 49 male and 68 female teachers took part in the study. Sixty three teachers were selected from Navid Institute and 54 teachers were from high schools. The number of years teachers had taught English varied, ranging from less than 5 years to more than 20 years. Teachers' age ranged from 20 to above 50 years old.

\subsection{Instrument}

In this study, a questionnaire was used to collect data related to the attitudes of language teachers. The content of the items in the questionnaire was based on an existing questionnaire (Ellis, 2003; Nunan, 2011) and the views of language teachers. Thirty EFL teachers who were currently teaching English at Navid Institute and high schools were asked to write their attitudes towards task-based language teaching in the form of a composition. In this composition, they were asked to define a task, provide their views on task-based language teaching, and write their practical reasons for implementing or avoiding the implementation of TBLT. Their writings were analyzed and categorized to find issues related to the purpose of the study, these issues together with those found in the literature were incorporated into the questionnaire. The questionnaire used in this study was constructed on a Likert Scale format, ranging from strongly agree to strongly disagree. The Cronbach Alpha reliability estimate of the questionnaire used for both groups was found to be 0.765 , showing that the internal consistency of the instrument was moderately high.

In order to further assess the internal consistency of the questionnaire, a correlation matrix was produced on the data by computing Pearson Product-moment correlations. A positive moderate correlation was found between task and TBLT $(r=.449)$, and a positive and low correlation between task and teachers' view $(r=0.213)$, and between TBLT and teachers' view $(\mathrm{r}=0.400)$.

The final version of the questionnaire employed for this study comprised two main sections. The first section of the questionnaire dealt with gender, educational contexts, years of teaching experience, and teachers' age. Section two of the questionnaire consisted of four main parts. In the first part, 10 items inquired about the participants' perceptions of the very concept of task. The second part of the questionnaire contains 12 items inquiring about the participants' perceptions of task-based language teaching and its principles and techniques. As for the third part, the instructors were asked to judge on 8 statements asking the participants whether they were interested in the implementation of task-based language lessons. In the final part, the participants were asked to indicate whether they were presently implementing task-based language teaching in their classes and were supposed to show their reasons why they used TBLT or avoided using it in their classes. 


\subsection{Data Collection Procedure}

The data collection for this study took place in two phases. In the first phase, thirty teachers were randomly selected from the two educational contexts and they were asked to write a composition regarding their attitudes towards TBLT. To be more specific, teachers were required to explain their viewpoints on TBLT and practical reasons behind implementing or avoiding the implementation of TBLT. Then, the collected viewpoints were analyzed and categorized to adapt the existing questionnaire. The designed questionnaire was then administered among thirty EFL teachers and the reliability was calculated. The reliability indices showed that the questionnaire enjoyed good reliability.

In the next phase of the study, fifty four high school teachers and sixty three private institute teachers were selected to take part in the study. Prior to conducting the study, the participants were informed about the purpose of the study and they were told that their answers will be kept confidential. In addition, they were informed that participation in the study was voluntary. In order to collect the data, the questionnaires were distributed among the instructors by visiting them at their schools and institutes. The questionnaire sought participants' demographic information as well as their viewpoints with respect to TBLT. The participants were required to answer to the items of the questionnaire on a Likert scale.

\subsection{Data Analysis Procedure}

In order to analyze the data of the questionnaire, the Likert-type items of the questionnaire were given a numerical score (e.g., strongly agree $=5$, agree $=4$, undecided $=3$, disagree $=2$, and strongly disagree $=1$ ). For the last section of the questionnaire which included open-ended items, the selected items were given the score of 1 and unselected items were given 0 . In order to find the association among the responses of the participants to each item, Chi-Square analysis of items was run. Statistical Package for the Social Sciences (SPSS) was used to analyze the data.

\section{Results}

The first research question of the study sought to explore private institute and high school teachers' perspectives regarding their knowledge of task. Accordingly, chi-squared test was used to compare the two groups with respect to their views on each item of the questionnaire. To facilitate the analysis, strongly disagree and disagree were considered together and strongly agree and agree were also regarded together. Table 2 presents the results of the analysis. 
Table 2. Comparison of private institute and high school teachers' knowledge of task

\begin{tabular}{|c|c|c|c|c|c|c|c|}
\hline \multirow[t]{2}{*}{ Item } & \multirow{2}{*}{$\begin{array}{l}\text { Educational } \\
\text { Context }\end{array}$} & \multicolumn{3}{|l|}{ Opinion } & \multirow[t]{2}{*}{$\mathrm{X}^{2}$} & \multirow[t]{2}{*}{ df } & \multirow[t]{2}{*}{ Sig. } \\
\hline & & $\mathrm{SD}+\mathrm{D}$ & $\mathrm{U}$ & $\mathrm{SA}+\mathrm{A}$ & & & \\
\hline \multirow[t]{2}{*}{ 1. A task is a work plan. } & Navid Institute & 16 & 13 & 34 & \multirow[t]{2}{*}{1.79} & \multirow[t]{2}{*}{2} & \multirow[t]{2}{*}{.407} \\
\hline & High School & 12 & 17 & 25 & & & \\
\hline \multirow[t]{2}{*}{ 2. A task involves a primary focus on meaning. } & Navid Institute & 16 & 8 & 39 & \multirow[t]{2}{*}{1.32} & \multirow[t]{2}{*}{2} & \multirow[t]{2}{*}{.515} \\
\hline & High School & 19 & 6 & 29 & & & \\
\hline \multirow[t]{2}{*}{ 3. A task is a real-world process of language use. } & Navid Institute & 2 & 4 & 57 & \multirow[t]{2}{*}{4.07} & \multirow[t]{2}{*}{2} & \multirow[t]{2}{*}{.131} \\
\hline & High School & 7 & 4 & 43 & & & \\
\hline \multirow{2}{*}{$\begin{array}{l}\text { 4. A task can involve any of the four language } \\
\text { skills. }\end{array}$} & Navid Institute & 8 & 6 & 49 & \multirow[t]{2}{*}{2.75} & \multirow[t]{2}{*}{2} & \multirow[t]{2}{*}{.252} \\
\hline & High School & 6 & 11 & 37 & & & \\
\hline \multirow[t]{2}{*}{ 5. A task engages cognitive processes. } & Navid Institute & 7 & 21 & 35 & \multirow[t]{2}{*}{2.72} & \multirow[t]{2}{*}{2} & \multirow[t]{2}{*}{.256} \\
\hline & High School & 12 & 17 & 25 & & & \\
\hline \multirow{2}{*}{$\begin{array}{l}\text { 6. Task is concerned with pragmatic meaning. } \\
\text { (The use of language in context) }\end{array}$} & Navid Institute & 13 & 18 & 32 & \multirow[t]{2}{*}{1.41} & \multirow[t]{2}{*}{2} & \multirow[t]{2}{*}{.494} \\
\hline & High School & 10 & 21 & 23 & & & \\
\hline \multirow{2}{*}{$\begin{array}{l}\text { 7. Any learning that takes place during the task is } \\
\text { incidental not intentional. }\end{array}$} & Navid Institute & 3 & 16 & 44 & \multirow[t]{2}{*}{4.33} & \multirow[t]{2}{*}{2} & \multirow[t]{2}{*}{.115} \\
\hline & High School & 6 & 20 & 28 & & & \\
\hline 8. A task is communicatively goal directed. & Navid Institute & 6 & 10 & 47 & 8.68 & 2 & .013 \\
\hline & High School & 11 & 17 & 26 & & & \\
\hline 9. A task has a clearly defined communicative & Navid Institute & 6 & 17 & 40 & 7.89 & 2 & .019 \\
\hline outcome. & High School & 16 & 13 & 25 & & & \\
\hline 10. A task is any activity in which the target & Navid Institute & 2 & 5 & 56 & 5.33 & 2 & .069 \\
\hline language is used by the learner. & High School & 5 & 10 & 39 & & & \\
\hline
\end{tabular}

( $\mathrm{SD}=$ Strongly Disagree, $\mathrm{D}=$ Disagree, $\mathrm{U}=$ Undecided, $\mathrm{A}=$ Agree, $\mathrm{SA}=$ Strongly Agree)

As Table 2 shows, the majority of the teachers in both educational contexts agreed with the items of questionnaire. As it can be seen, the number of teachers who agreed with the items of the questionnaire is higher than teachers in high school. However, as the results of the Chi-Square indicate, the two groups only differed significantly on two items. The result indicates that teachers' view differed on item 8 "A task is communicatively goal directed", $\mathrm{X} 2(2, \mathrm{~N}=117)$ $=8.68, \mathrm{p}=.013$; and item 9 "A task has a clearly defined communicative outcome", $\mathrm{X} 2(2, \mathrm{~N}=117)=7.89, \mathrm{p}=.019$.

The second research question of the study sought to gauge teachers' knowledge of TBLT principles. Chi-square test was employed to analyze the data. Table 3 presents the result of the analysis. 
Table 3. Comparison of private institute and high school teachers' knowledge of TBLT principles

\begin{tabular}{|c|c|c|c|c|c|c|c|}
\hline \multirow[t]{2}{*}{ Item } & \multirow{2}{*}{$\begin{array}{l}\text { Educational } \\
\text { Context }\end{array}$} & \multicolumn{3}{|c|}{ Opinion } & \multirow[t]{2}{*}{$\mathrm{X} 2$} & \multirow[t]{2}{*}{$\mathrm{df}$} & \multirow[t]{2}{*}{ Sig. } \\
\hline & & $\mathrm{SD}+\mathrm{D}$ & $\mathrm{U}$ & $\mathrm{SA}+\mathrm{A}$ & & & \\
\hline \multirow{2}{*}{$\begin{array}{l}\text { 1. TBLT is consistent with the principles of } \\
\text { communicative language teaching }\end{array}$} & Navid Institute & 2 & 7 & 54 & \multirow[t]{2}{*}{14.6} & \multirow[t]{2}{*}{2} & \multirow[t]{2}{*}{.001} \\
\hline & High School & 8 & 17 & 29 & & & \\
\hline \multirow{2}{*}{$\begin{array}{l}\text { 2. TBLT is based on the student-centered } \\
\text { instructional approach }\end{array}$} & Navid Institute & 5 & 11 & 47 & \multirow[t]{2}{*}{1.80} & \multirow[t]{2}{*}{2} & \multirow[t]{2}{*}{.406} \\
\hline & High School & 4 & 15 & 35 & & & \\
\hline \multirow{2}{*}{$\begin{array}{l}\text { 3. Pre- task activities can consists of: performing } \\
\text { a similar task, providing a model, Non- task } \\
\text { preparation activities and strategic planning. }\end{array}$} & Navid Institute & 8 & 7 & 48 & \multirow[t]{2}{*}{5.31} & \multirow[t]{2}{*}{2} & \multirow[t]{2}{*}{.070} \\
\hline & High School & 6 & 15 & 33 & & & \\
\hline \multirow{2}{*}{$\begin{array}{l}\text { 4. During task phase, centers on the task itself and } \\
\text { affords various instructional options including } \\
\text { whether students are required to operate under } \\
\text { time pressure or not. }\end{array}$} & Navid Institute & 10 & 12 & 41 & \multirow[t]{2}{*}{6.45} & \multirow[t]{2}{*}{2} & \multirow[t]{2}{*}{.040} \\
\hline & High School & 11 & 20 & 23 & & & \\
\hline \multirow{2}{*}{$\begin{array}{l}\text { 5. The final phase is post-task involves procedures } \\
\text { following up on the task performance. }\end{array}$} & Navid Institute & 4 & 7 & 52 & \multirow[t]{2}{*}{3.14} & \multirow[t]{2}{*}{2} & \multirow[t]{2}{*}{.208} \\
\hline & High School & 6 & 11 & 37 & & & \\
\hline \multirow[t]{2}{*}{ 6. TBLT is based on referential questions } & Navid Institute & 7 & 18 & 38 & \multirow[t]{2}{*}{2.18} & \multirow[t]{2}{*}{2} & \multirow[t]{2}{*}{.335} \\
\hline & High School & 11 & 16 & 27 & & & \\
\hline \multirow[t]{2}{*}{ 7. TBLT is based on display questions } & Navid Institute & 15 & 19 & 29 & \multirow[t]{2}{*}{.332} & 2 & .847 \\
\hline & High School & 14 & 18 & 22 & & & \\
\hline 8. TBLT includes opportunities to negotiate & Navid Institute & 6 & 9 & 48 & 4.72 & 2 & .094 \\
\hline meanıng when communication problems arise. & High School & 10 & 13 & 31 & & & \\
\hline 9. TBLT is based on content- focused feedback & Navid Institute & 5 & 16 & 42 & 4.09 & 2 & .129 \\
\hline rather than form focused feedback. & High School & 11 & 14 & 29 & & & \\
\hline 10. TBLT is based on loose discourse structure. & Navid Institute & 13 & 21 & 29 & 1.21 & 2 & .546 \\
\hline & High School & 15 & 19 & 20 & & & \\
\hline 11. TBLT is based on rigid discourse structure. & Navid Institute & 29 & 18 & 16 & .797 & 2 & .671 \\
\hline & High School & 27 & 17 & 10 & & & \\
\hline 12. TBLT is based on active learning, the students & Navid Institute & 5 & 11 & 47 & 3.12 & 2 & .210 \\
\hline learn by doing. & High School & 7 & 15 & 32 & & & \\
\hline
\end{tabular}

( $\mathrm{SD}=$ Strongly Disagree, $\mathrm{D}=$ Disagree, $\mathrm{U}=$ Undecided, A=Agree, SA=Strongly Agree)

Table 3 presents the results of analysis for the third part of the questionnaire which explored teachers' knowledge of TBLT. As the table indicates, most of the teachers in both groups agreed on the majority of the items. According to the table, the responses of teachers differed significantly in two items, including item 1 "TBLT is consistent with the principles of communicative language teaching", $\mathrm{X} 2(2, \mathrm{~N}=117)=14.69, \mathrm{p}=.001$; and item 4 "During task phase, centers around the task itself and affords various instructional options including whether students are required to operate under time pressure or not", $\mathrm{X} 2(2, \mathrm{~N}=117)=6.45, \mathrm{p}=.040$. In item 1 and 4 , the number of teachers in private institute who agreed with the items is higher than the number of teachers in high school.

Chi-square test was also employed to analyze the data regarding teachers' perspective regarding TBLT implementation. Table 4 provides the result of the analysis. 
Table 4. Comparison of high school and private institute teachers' view of implementing TBLT

\begin{tabular}{|c|c|c|c|c|c|c|c|}
\hline \multirow[t]{2}{*}{ Item } & \multirow{2}{*}{$\begin{array}{c}\text { Educational } \\
\text { Context }\end{array}$} & \multicolumn{3}{|c|}{ Opinion } & \multirow[t]{2}{*}{$\mathrm{X} 2$} & \multirow[t]{2}{*}{ df } & \multirow[t]{2}{*}{ Sig. } \\
\hline & & $\mathrm{SD}+\mathrm{D}$ & $\mathrm{U}$ & $\mathrm{SA}+\mathrm{A}$ & & & \\
\hline \multirow{2}{*}{$\begin{array}{l}\text { 1. I have interest in implementing TBLT in the } \\
\text { classroom }\end{array}$} & Navid Institute & 6 & 9 & 48 & \multirow[t]{2}{*}{4.55} & \multirow[t]{2}{*}{2} & \multirow[t]{2}{*}{.103} \\
\hline & High School & 13 & 7 & 34 & & & \\
\hline \multirow{2}{*}{$\begin{array}{l}\text { 2. TBLT provides a relaxed atmosphere to } \\
\text { promote the target language use. }\end{array}$} & Navid Institute & 9 & 13 & 41 & \multirow[t]{2}{*}{2.71} & \multirow[t]{2}{*}{2} & \multirow[t]{2}{*}{.257} \\
\hline & High School & 11 & 16 & 27 & & & \\
\hline \multirow[t]{2}{*}{ 3. TBLT activates learners' needs and interests } & Navid Institute & 9 & 15 & 39 & \multirow[t]{2}{*}{.527} & \multirow[t]{2}{*}{2} & \multirow[t]{2}{*}{.768} \\
\hline & High School & 9 & 10 & 35 & & & \\
\hline \multirow{2}{*}{$\begin{array}{l}\text { 4. TBLT pursues the development of integrated } \\
\text { skills in the classroom. }\end{array}$} & Navid Institute & 5 & 16 & 42 & \multirow[t]{2}{*}{2.25} & \multirow[t]{2}{*}{2} & \multirow[t]{2}{*}{.324} \\
\hline & High School & 9 & 14 & 31 & & & \\
\hline \multirow{2}{*}{$\begin{array}{l}\text { 5. TBLT gives much psychological burden to a } \\
\text { teacher as a facilitator. }\end{array}$} & Navid Institute & 6 & 11 & 46 & \multirow[t]{2}{*}{.866} & \multirow[t]{2}{*}{2} & \multirow[t]{2}{*}{.649} \\
\hline & High School & 8 & 10 & 36 & & & \\
\hline \multirow{2}{*}{$\begin{array}{l}\text { 6. TBLT requires much time preparation } \\
\text { compared to other approaches }\end{array}$} & Navid Institute & 8 & 18 & 37 & \multirow[t]{2}{*}{.559} & \multirow[t]{2}{*}{2} & \multirow[t]{2}{*}{.756} \\
\hline & High School & 5 & 14 & 35 & & & \\
\hline \multirow{2}{*}{$\begin{array}{l}\text { 7. TBLT is proper for controlling classroom } \\
\text { arrangements. }\end{array}$} & Navid Institute & 8 & 16 & 39 & \multirow[t]{2}{*}{.28} & \multirow[t]{2}{*}{2} & \multirow[t]{2}{*}{.867} \\
\hline & High School & 6 & 12 & 36 & & & \\
\hline \multirow{2}{*}{$\begin{array}{l}\text { 8. TBLT materials should be meaningful and } \\
\text { purposeful based on the real-world context. }\end{array}$} & Navid Institute & 4 & 14 & 45 & \multirow[t]{2}{*}{2.32} & 2 & .313 \\
\hline & High School & 8 & 10 & 36 & & & \\
\hline
\end{tabular}

( $\mathrm{SD}=$ Strongly Disagree, $\mathrm{D}=$ Disagree, $\mathrm{U}=$ Undecided, $\mathrm{A}=$ Agree, $\mathrm{SA}=$ Strongly Agree $)$

Table 4 presents the result of the analysis for the fourth part of the questionnaire which investigated high school and private institute teachers' view of implementing TBLT in the classroom. As the table shows, all the teachers in the two groups have positive attitudes toward implementing TBLT in their classes as the frequency of participants who agreed with the items is higher than those who disagreed. Moreover, there was no statistically significant difference between the two groups since the $\mathrm{p}$ value was higher than .05 for each item.

Table 5 and 6 present the results of teachers' view regarding the reasons for the implementation and avoiding the implementation of TBLT in the classroom. 
Table 5. Reasons for implementing TBLT

\begin{tabular}{lcc}
\hline Item & Educational Context \\
\cline { 2 - 3 } & Navid Institute & High School \\
\hline $\begin{array}{l}\text { 1. TBLT motivates learners' to consider language form in general rather } \\
\text { than concentrating on a single form (ppp model) }\end{array}$ & 24 & 12 \\
$\begin{array}{l}\text { 2. TBLT helps learners' to integrate all four skills and to move from } \\
\text { fluency to accuracy }\end{array}$ & 43 \\
$\begin{array}{l}\text { 3. TBLT encourages learners' intrinsic motivation. } \\
\text { 4. TBLT offers a great deal of flexibility }\end{array}$ & 35 \\
$\begin{array}{l}\text { 5. TBLT creates a collaborative learning environment that real } \\
\text { communication should take place. }\end{array}$ & 37 \\
$\begin{array}{l}\text { 6. TBLT is appropriate for small group work. } \\
11\end{array}$ & 22 \\
\hline
\end{tabular}

As Table 5 indicates, from among the six reasons for implementing TBLT in classroom, 43 teachers in Navid Institute selected the second item (TBLT helps learners' to integrate all four skills and to move from fluency to accuracy) as the basic reason for implementing TBLT in the classroom. Item 5 and item 3 are the two other reasons that teachers choose to employ TBLT in the classroom. Item 4 is the least selected reason for implementing TBLT since only 17 teachers selected that. Teachers in high school also selected item 2 as the basic reason for implementing TBLT in the classroom. The least selected reason is the sixth one (TBLT is appropriate for small group work) which only 8 teachers selected that.

Table 6. Reasons for not implementing TBLT

\begin{tabular}{lcc}
\hline Item & \multicolumn{2}{c}{ Educational Context } \\
\cline { 2 - 3 } 1. Students are not used to task-based learning. & Navid Institute & 30 \\
2. Materials in textbooks are not proper for using TBLT. & 24 & 34 \\
3. Large class size is an obstacle to use task-based methods & 19 & 42 \\
4. I have difficulty in assessing learner's task-based performance & 17 & 25 \\
5. I have limited target language proficiency. & 9 & 13 \\
6. I have very little knowledge of task-based instruction. & 13 & 21 \\
\hline
\end{tabular}

As Table 6 reveals, 24 teachers in Navid Institute selected item 1 as the basic reason for avoiding the implementation of TBLT in the classroom. The second and third most selected reasons were item 2 and 3 , respectively. According to the table, the lowest frequency refers to item 5 which only 9 teachers selected that. For high school teachers, item 3 has the highest frequency which means that teachers selected this reason as the basic one for avoiding the implementation of TBLT in the classroom. The two other most selected reasons are item 2 and 1 with 34 and 30 teachers selecting them, respectively. Thirteen teachers in high school selected item 5 which makes it the least selected reason for avoiding the implementation of TBLT.

\section{Discussion}

The analysis of the responses to the 10 items of the questionnaire indicated that the majority of the teachers in both educational contexts had a good knowledge of task and its principles. No significant difference was found between the two groups except for two items. As the result indicated, teachers' view at high school and private institute differed with respect to the communicative aspect of the task. Accordingly, the first hypothesis of the study is rejected. The 
overall findings of this section of the questionnaire are in line with the previous findings which indicated that teachers have shown good grasp of task and its aspects (Jeon, 2005; Lin \& Wu, 2012; Tabatabaei \& Hadi, 2011; Zare, 2007). For example, Lin and $\mathrm{Wu}(2012)$ found that teachers had both positive attitudes and understanding of tasks and taskrelated issues. This might be due to the fact that the Asian EFL context has witnessed a move toward the use of a taskbased and activity oriented type of learning a language (Jeon, 2005).

The second hypothesis of the study mentioned that there is no significant difference between high school and private institute teachers' perceptions of TBLT. As the results of the analysis revealed, the majority of teachers had good knowledge of TBLT principles. Except for item 1 and 4, no significant difference was observed between the two groups. Teachers in private institute had higher level of knowledge with respect to these two items. Accordingly, the second hypothesis of the study is rejected. The findings of the study are in line with the previous studies conducted by Ilin, Inozu, and Yumru (2007), Bogali (2009), and Xiongyong and Samuel (2011). Bogali (2009) mentioned that EFL instructors had high levels of perception about TBLT theories. However, the findings are in contrast with the findings of Carless (2002) and Littlewood (2004) who found that teachers indicated a lack of theoretical knowledge of TBLT.

The third hypothesis of the study stated that there is no significant difference between high school and private institute teachers' attitude towards the implementation of TBLT. According to results, most of the teachers in both educational contexts had positive attitude toward implementing TBLT. Moreover, there was no significant difference between teachers' view in both contexts. Accordingly, the third hypothesis of the study is retained. The findings are in similar line with previous study by Jeon and Hahn (2006). The reason could be the one mentioned by Jeon and Hahn (2006) who said that due to limited accessibility to use language on a daily basis, the teachers believed it is necessary to provide the learners with ample opportunities to be exposed to real language use in the classroom situation within the framework of task-based language teaching. However, the findings are in contrast with the study conducted by Ansari and Shahrokhi (2014). They suggested that teachers' beliefs regarding language and language learning affect the way they employ instructional practices in the classroom. In their study, however, they found that despite teachers' clear perception of TBLT principles, the majority of the teachers stated their reluctance to implement TBLT techniques in classroom.

With respect to the last research question of the study which sought to investigate the reasons for implementing TBLT and reasons for avoiding the implementation of TBLT, the result indicated that the teachers in both educational context attempt to use TBLT since they believed that it helps learners to integrate all four skills and to move from fluency to accuracy. This is in line with the study conducted by Carless (2002) and Watson (2006) who claimed that teachers use TBLT since they are concerned about students' language proficiency. Moreover, teachers in high school stated that they do not use TBLT due to large class size. Jeon and Hahn (2006) also stated that teachers avoid using TBLT due classes with large enrollments. Unlike the institutes' teachers, high school teachers stated that materials in textbooks are not proper for using TBLT. Moreover, learners at high school are not familiar with task-based instruction; as a result, teachers avoid using TBLT in their classes. In similar line, Jeon and Hahn (2006) claimed that students' unfamiliarity with this learning process prevent teachers from using TBLT in the classroom.

\section{Conclusion}

Generally, the findings of this study indicated that most of Iranian EFL teachers in Navid Institute and high schools have high perception of TBLT concepts. Moreover, Iranian teachers showed positive attitudes toward using TBLT in the classroom. The study also indicated that despite a higher level of understanding of TBLT concepts, not many Iranian EFL teachers employ TBLT in the classes due to some limitations related to classroom practice. Based on the findings of the study, a number of implications are proposed. First and foremost, teachers play a key role in classroom. Their positive attitude toward instructional approach (in the case of this study, TBLT) is necessary for successful implementation of the approach. Second, although the teachers in high schools are not accustomed to learnercenteredness in teaching in the educational system, it does not mean that they should put TBLT aside and follow traditional methods of language teaching.

Third, teachers training courses (TTC), in-service teachers' updates, as well as occasional workshops need to be targeted at promoting teachers' knowledge of the latest methods and theories of teaching and learning. They are also required to elaborate on the underlying principles of the theoretical, psychological, and pedagogical rationale behind the proposed classroom activities, the reason behind the selection and sequencing of the exercises which are put forward in textbooks. Indeed, teachers' awareness of the underlying principles of prescribed pedagogical activities 
convinces them to willingly adapt their classrooms activities to new and improved methods of language teaching. Especially in the case of this study teachers should be aware of the multidimensional aspect of task-based language teaching. Forth, the results indicated a welcoming atmosphere toward the implementation of task, which provided the basis for pedagogic decisions about grading and sequencing tasks.

For future line of study, it is suggested that researchers investigate the attitudes of teachers in primary or secondary schools toward implementing TBLT in the classes. The present study dealt with the views of teachers toward task and TBLT. A research can be done based on the comparison of teachers' views on the traditional methods of teaching and task-based language teaching on L2 development. Studying whether TBLT works as well for children as for adults can end up yielding fruitful results concerning the implementation of TBLT.

\section{References}

Alavi, S. M. (2003). Task-based teaching: Can it be applied in Iranian high schools? Paper presented at the nationwide conference of English language teachers' organization, Hamedan, Iran.

Ansari, K., \& Shahrokhi, M. (2014). Iranian teachers' conceptions of task-based language teaching: A case study of 40 English teachers in Gacsaran. International Journal of Language Learning and Applied Linguistics World, 7(3), 122-137.

Barnard, R., \& Nguyen, V. (2010). Task based language teaching (TBLT): A Vietnamese case study using narrative frames to elicit teachers' beliefs. Language Education in Asia, 1, 77-86. doi: 10.5746/LEiA/10/V1/A07/Barnard_Nguyen

Beglar, D., \& Hunt, A. (1999). Implementing task-based language teaching. In J. C. Richards \& W. A. Renandya, Methodology in language teaching. Cambridge University Press.

Benevides, M., \& Valvona, C. (2008). Widgets: A task-based course in practical English. Hong Kong: Pearson Longman.

Borg, S. (2006). The distinctive characteristics of foreign language teachers. Language Teaching Research, 10(1), 331. https://doi.org/10.1191/13621688061r182oa

Carless, D. (2002). Implementing task-based learning with young learners. ELT Journal, 56(4), 389-396. https://doi.org/10.1093/elt/56.4.389

Ellis, R. (2003). Task-based language learning and teaching. Oxford University Press.

Ellis, R. (2006). The methodology of task-based teaching. Asian EFL Journal, 8(3), 19-46. https://www.asian-efljournal.com/main-journals/the-methodology-of-task-based-teaching/

Ellis, R., \& Shintani, N. (2014). Exploring language pedagogy through second language acquisition research. New York, NY: Routledge.

Farrell, T. S., \& Kun, S. T. K. (2007). Language policy, language teachers' beliefs, and classroom practices. Applied Linguistics, 29(3), 381-403. https://doi.org/10.1093/applin/amm050

Ilin, G., Inozu, J., \&Yumru, H. (2007). Teachers' and learners' perceptions of Tasks: Objectives and outcomes. Journal of Theory and Practice in Education, 3(1), 60-68. https://dergipark.org.tr/en/pub/eku/issue/5445/73887

Jeon, I, J. (2005). An analysis of task-based materials and performance: Focused on Korean high school English textbooks. English Teaching, 60(2), 87-109. https://www.semanticscholar.org/paper/Exploring-EFLTeachers-\%E2\%80\%99-Perceptions-of-Task-Based-Jeon/f94614b7737787cb38cecf413d63058e4cd77dd8

Jeon, I. J., \& Hahn, J. W. (2006). Exploring EFL teachers' perceptions of task-based language teaching: A case study of Korean secondary school classroom practice. Asian EFL Journal, 8(1), 123-143. http://www.asian-efljournal.com/March06_ijj\&jwh.pdf

Lin, T. B., \& Wu, C. W. (2012). Teachers' perceptions of task-based language teaching in English classrooms in Taiwanese junior high schools. TESOL Journal, 3(4), 586-609. https://doi.org/10.1002/tesj.35

Littlewood, W. (2004). The task-based approach: Some questions and suggestions. ELT Journal, 58(4), $319-326$. https://doi.org/10.1093/elt/58.4.319 
Liu, Y., Mishan, F., \& Chambers, A. (2018). Investigating EFL teachers' perceptions of task-based language teaching in higher education in China. The Language Learning Journal, 1-16. https://doi.org/10.1080/09571736.2018.1465110

Long, M. H., \& Crookes, G. (1992). Three approaches to task-based syllabus design. TESOL Quarterly, 26(1), 27-56. https://doi.org/10.2307/3587368

Long, M., \& Norris, J. (2009). Task-based teaching and assessment. In: van den Branden, Kris, Bygate, Martin, Norris, John (Eds.), Task-based language teaching: a Reader. John Benjamins, Amsterdam, pp. 135-142.

Mahdavirad, F. (2017). Task-Based Language Teaching in Iran: A Study of EFL Teachers' Perspectives. International Journal of English Language \& Translation Studies, $5(4), \quad$ 14-21. http://www.eltsjournal.org/archive/value5\%20issue4/3-5-4-17.pdf

Nunan, D. (1988). The learner-centered curriculum: A study in second language teaching. Cambridge University Press.

Nunan, D. (2011). Task-based language teaching. Cambridge: Cambridge University Press.

Parrott, M. (1993). Tasks for language teachers. Ernst Klett Sprachen.

Pham, N. T., \& Nguyen, H. B. (2018). Teachers' perceptions about task-based language teaching and its implementation. European Journal of Foreign Language Teaching, 3(2), 68-86. http://doi.org/10.5281/zenodo.1241474

Pohan, E., Andhini, E., Nopitasari, E., \& Levana, Y. (2016). Teachers' perceptions of task-based language teaching in English classroom. Proceedings of ISELT FBS Universitas Negeri Padang, 4(1), 256-265. https://www.researchgate.net/publication/322750289_Teachers'_Perceptions_of_Task-

Based_Language_Teaching_in_English_Classroom

Richards, J., \& Rodgers, T. (2001). Approaches and methods in language teaching. New York: Cambridge University Press.

Skehan, P., \& Foster, P. (1999). The influence of structure and processing conditions on narrative retellings. Language Learning, 49(3), $93-120$.

Tabatabaei, O., \& Hadi, A. (2011). Iranian EFL teachers' perceptions of task-based language pedagogy. Higher Education of Social Science, 1(2), 1-9. http://dx.doi.org/10.3968/j.hess.1927024020110102.1566

Watson Todd, R. (2006). Continuing change after the innovation. System, 34(1), 1-14. doi:10.1016/j.system.2005.09.002

Willis, D., \& Willis, J. (2009). Task-based language teaching: Some questions and answers. The Language Teacher, 33(3), 3-8. https://jalt-publications.org/tlt/articles/562-special-issue-task-based-learning-somequestions-and-answers

Willis, J. (1996). A framework for task-based learning. Harlow, England: Longman.

Xiongyong, C., \& Moses, S. (2011). Perceptions and implementation of task-based language teaching among secondary school EFL teachers in China. International Journal of Business and Social Science, 2(24), 292302. http://ijbssnet.com/journal/index/997

Zare, G. (2007). The attitudes of the Iranian EFL learners and teachers towards task-based language teaching. (Unpublished MA thesis). Shiraz University, Shiraz, Iran. 